\title{
ANTIBACTERIAL ACTIVITY AND MECHANISM OF ACTION OF THE WASP VESPA ORIENTALIS VENOM PEPTIDES
}

\author{
Asmaa E. Amer; Eman E. Essa ; Magda H. Rady; Adel K. Al-Sayed; \\ Dalia M. Mahmoud
}

Entomology Department, Faculty of Science, Ain Shams University, Cairo, Egypt

\begin{abstract}
Article History:
Received: 18 November 2020

Revised: 23 January 2021

Accepted: 25 January 2021

Published Online:

29 January 2021

Keywords:

Antimicrobial peptides

Resistant bacteria

SDS-PAGE

Vespa orientalis

Wasp venom

*Correspondence:

Eman Essa

Entomology Department

Faculty of Science

Ain Shams University

Cairo, Egypt

E-mail:

eman.essa@sci.asu.edu.eg

ABSTRACT

Recently several insects have been identified as potential carriers of antimicrobial peptides (AMPs), which have potent activity against pathogens. Wasp venom AMPs serve as defense agents against invading microorganisms. AMPs derived from wasp venom have high attention as therapeutic agents against infectious agents with novel mechanisms of action. In the present study, the antibacterial activity of the oriental hornet "Vespa orientalis L. (Hymenoptera: Vespidae)" venom was determined against three Gram-positive and three Gram-negative bacteria; and the minimum concentration of the venom that inhibits the bacterial growth was determined. Sodium dodecyl sulfate-polyacrylamide gel electrophoresis (SDS-PAGE) technique was used for fractionation of the $V$. orientalis venom peptides. The effect of $V$. orientalis AMPs on bacterial cell membrane and cytoplasm was also investigated; destruction of bacterial cell wall inhibited steps of the synthesis of important molecules and caused cell death. The results proved the highly effective antibacterial properties of the $V$. orientalis venom. Therefore, peptides of the $V$. orientalis venom could be potential alternative agents to the currently-used antibiotics.
\end{abstract}

\section{INTRODUCTION}

Insects provide experimentally tractable and cost-effective model systems to much product development for many purposes in many aspects. Wasps are a valuable source of both chitosan from their chitin $^{[1,2]}$ and antimicrobial peptides (AMPs) from their venoms ${ }^{[3]}$. Vespid venoms consist of a mixture of allergens and pharmacologically compounds made up of proteins $^{[3]}$. Stinging hymenopteran species produce venoms that include enzymes (hyaluronidases and phospholipases), neurotoxin, peptides, ionized molecules, and neurotransmitters. AMPs are part of the wasp venom, which act as defense against microorganisms harbored by its insect victim $^{[4]}$.

The widespread and inappropriate use of antibiotics against pathogenic microorganisms had led to increase microbial resistance $^{[5]}$. This resistance is responsible for increasing costs of hospitalization and treatment, which burdens the health care system. It is suggested that within ten years no antibiotics effective treatment against pathogens would be available ${ }^{[6]}$. Current investigations for determining new 
antibacterial agents to overcome resistance are a must. We examined in the current study the antibacterial activity of oriental hornet "Vespa orientalis" venom peptides using a variety of antimicrobial susceptibility tests and have utilized some antibioticresistant pathogenic bacteria to determine the potential of $V$. orientalis venom to serve as an alternative therapeutic agent for bacterial infection.

\section{MATERIAL AND METHODS}

\section{Collection of $\boldsymbol{V}$. orientalis samples}

Oriental hornet " $V$. orientalis" samples were collected during summer season (July - September, 2019) from hornet traps, which settled between the honeybee nests at the department of honey bee researches, Institute of plant protection, Ministry of Agriculture (Giza, Egypt). The traps were placed to trap $V$. orientalis during feeding on honey and bee workers.

\section{Venom extraction}

The venom was collected from the $V$. orientalis by the electrical shock method $^{[7]}$. The collected venom was packed in opaque glass vials and kept at $5.0^{\circ} \mathrm{C}$ till used.

\section{Bacterial isolates}

Gram-positive bacteria such as Bacillus subtilis (RCMB015), methicillin-resistant Staphylococcus aureus (MRSA), and Streptococcus mutans (RCMB017), as well as Gram-negative bacteria such as Escherichia coli (RCMB010052), Klebsiella pneumonia (RCMB003), and Salmonella typhimurium (RCMB006), were used to measure the activity of the $V$. orientalis venom. These genera were obtained from the regional center for mycology and biotechnology, AL-Azhar University (Cairo, Egypt). The bacterial cultures were obtained on nutrient agar (Hi media) by slant streak technique according to the method of Mackie and McCartney ${ }^{[8]}$. Stock culture of each bacterial strain was maintained in $20 \%$ glycerol and stored at $-80^{\circ} \mathrm{C}$.

\section{Antibacterial activity of $V$. orientalis venom}

The classical agar disk diffusion method ${ }^{[9]}$ was used during measuring the antibacterial activity of $V$. orientalis venom. Paper disk, about $6.0 \mathrm{~mm}$ in diameter were loaded with the venom extract $(30 \mu \mathrm{g})$ and spread on bacterial agar plates, and left for 2 hours in a refrigerator for diffusion, then incubated at $37^{\circ} \mathrm{C}$ for 24 hours. The resultant inhibition zones were measured according to the method of Holder and Boyce ${ }^{[10]}$. The inhibitory action of tetracycline antibiotic against the same bacterial strains was used for comparison.

\section{Determination of the minimum inhibitory concentrations (MIC)}

Different concentrations of $V$. orientalis venom were used (from $2 \times 10^{-7}$ to 20.0 $\mathrm{mg} / \mathrm{mL})$. The microtiter broth dilution method was used to estimate the minimum inhibitory concentration of $V$. orientalis venom against all tested bacterial types according to the method of Jalaei et al. ${ }^{[9]}$. The percentage of inhibition of bacterial growth was calculated as follow ${ }^{[9]}$ :

Bacterial growth inhibition $(\%)=100-$ [(O.D of venom containing wells - O.D of background control) / (O.D of growth control - O.D of background control) $] \times 100$

Where O.D is the optical density readings of the bacterial growth, tetracycline antibiotic was used for comparison.

\section{Transmission electron microscopy (TEM)}

The changes in the shape and the structure of the treated bacterial strains with $V$. orientalis venom were detected using TEM (JEOL1010, JEOL Inc., Peabody, MA, USA) technique ${ }^{[11]}$.

\section{Venom protein analysis}

One dimensional gel electrophoresis was carried out using sodium dodecyl sulfate (SDS)-polyacrylamide gel slabs (15\%) as described by Laemmli gel method ${ }^{[12]}$, which was used to characterize the protein configuration of $V$. orientalis venom. 


\section{RESULTS}

Antibacterial activity of $V$. orientalis venom comparing with tetracycline

The crude $V$. orientalis venom caused a significant inhibition rate in bacterial growth as follows: 19, 18, 10, 18, 16 and $7 \mathrm{~mm}$ for Staphylococcus aureus, Bacillus subtilis, Streptococcus mutans, Escherichia coli, Klebsiella pneumonia, and Salmonella typhimurium, respectively, compared with lower values of inhibition of tetracycline $(10,14,16,15,14$ and $19 \mathrm{~mm}$, respectively) except against Streptococcus mutans and Salmonella typhimurium, where its inhibitory activities were high. Most of tested bacterial strains showed a susceptibility to the tested venom; whereas MRSA was the most sensitive one. Also, the present findings indicate that the crude venom is more effective against grampositive than gram-negative bacteria. Results of MIC in Table "1" confirmed the activity of $V$. orientalis venom against all tested bacteria. The bacterial inhibition activity after venom application was higher compared with that formed by tetracycline, except for Salmonella typhimurium and Streptococcus mutans where tetracycline was effective than the $V$. orientalis venom.

Table 1: Minimum inhibitory concentrations (MIC) and percentage of inhibition of Vespa orientalis venom against Gram-positive and Gram-negative bacteria compared with tetracycline.

\begin{tabular}{lcccc}
\hline Bacteria & $\begin{array}{c}\text { MIC of } \\
\text { Vespa orientalis } \\
\text { venom }(\mathrm{mg} / \mathrm{mL})\end{array}$ & $\begin{array}{c}\text { Inhibition } \\
(\%)\end{array}$ & $\begin{array}{c}\text { MIC of } \\
\text { tetracycline } \\
\text { antibiotic }(\mathrm{mg} / \mathrm{mL})\end{array}$ & $\begin{array}{c}\text { Inhibition } \\
(\%)\end{array}$ \\
\hline Gram-positive bacteria & $2.0 \times 10^{-8}$ & 4.74 & $2.0 \times 10^{-3}$ & 2.5 \\
MRSA & $2.0 \times 10^{-7}$ & 14.38 & $2.0 \times 10^{-5}$ & 7.19 \\
Bacillus subtilis & $2.0 \times 10^{-3}$ & 8.88 & $2.0 \times 10^{-7}$ & 11.11 \\
Streptococcus mutans & & & & \\
\hline Gram-negative bacteria & $2.0 \times 10^{-4}$ & 8.6 & $2.0 \times 10^{-3}$ & 6.7 \\
Escherichia coli & $2.0 \times 10^{-4}$ & 16.0 & $2.0 \times 10^{-3}$ & 9.39 \\
Klebsiella pneumonia & $2.0 \times 10^{-2}$ & 3.1 & $2.0 \times 10^{-6}$ & 10.85 \\
Salmonella typhimurium & & & & \\
\hline
\end{tabular}

MRSA: methicillin-resistant Staphylococcus aureus

\section{V. orientalis venom protein fractions}

The electrophoretically separated protein fractions of $V$. orientalis venom are shown in Table " 2 ". The results revealed that the total number of peptide bands resolved on $15 \%$ SDS polyacrylamide gel were seven polypeptide bands with molecular masses $310.0,227.8,186.8,116.5$, 73.1, 68.9, and $60.9 \mathrm{kDa}$ and percentage amount $4.5,2.6,3.2,2.4,12.8,6.3$, and $2.8 \%$, respectively.

Ultrastructural changes of $V$. orientalis venom-treated bacteria

The ultrastructural sections of untreated MRSA, Bacillus subtilis, and Escherichia coli (Figures 1a, 2a and 3a) showed intact cell membrane and cell wall, uniform cell cytoplasm with a distinct membrane, and clear normal cell division and structure. Treatment of MRSA with the $V$. orientalis venom (MIC: $2.0 \times 10^{-8} \mathrm{mg} / \mathrm{mL}$ ) showed contraction of cytoplasmic contents, loss of cytoplasmic electron density, cell rupture and loss of its contents, and the cell appeared empty (Figure 1b). The examination of the ultrastructure of MRSA cells after treatment with tetracycline (MIC: $2.0 \times 10^{-3}$ ) showed that cells were marginally influenced with moderate film blebbing and cytoplasm misplaced its electron thickness properties (Figure 1c). 
Table 2: Relative concentrations of fractionated protein bands detected in venom of Vespa orientalis.

\begin{tabular}{|c|c|c|c|}
\hline \multirow[b]{2}{*}{ Rows } & \multirow{2}{*}{$\begin{array}{c}\text { Marker } \\
\begin{array}{c}\text { Molecular weight } \\
(\mathrm{kDa})\end{array}\end{array}$} & \multicolumn{2}{|c|}{ Venom } \\
\hline & & $\begin{array}{l}\text { Molecular weight } \\
(\mathrm{kDa})\end{array}$ & Amount (\%) \\
\hline 1 & & 310.0 & 4.5 \\
\hline 2 & 245 & 227.8 & 2.6 \\
\hline 3 & 180 & 186.8 & 3.2 \\
\hline 4 & 135 & & \\
\hline 5 & 100 & 116.5 & 2.4 \\
\hline \multicolumn{4}{|l|}{6} \\
\hline 7 & 75 & 73.1 & 12.8 \\
\hline \multicolumn{4}{|l|}{8} \\
\hline 9 & & 68.9 & 6.3 \\
\hline 10 & 63 & 60.9 & 2.8 \\
\hline 11 & 48 & & \\
\hline 12 & 35 & & \\
\hline 13 & 25 & & \\
\hline 14 & 20 & & \\
\hline 15 & 17 & & \\
\hline
\end{tabular}

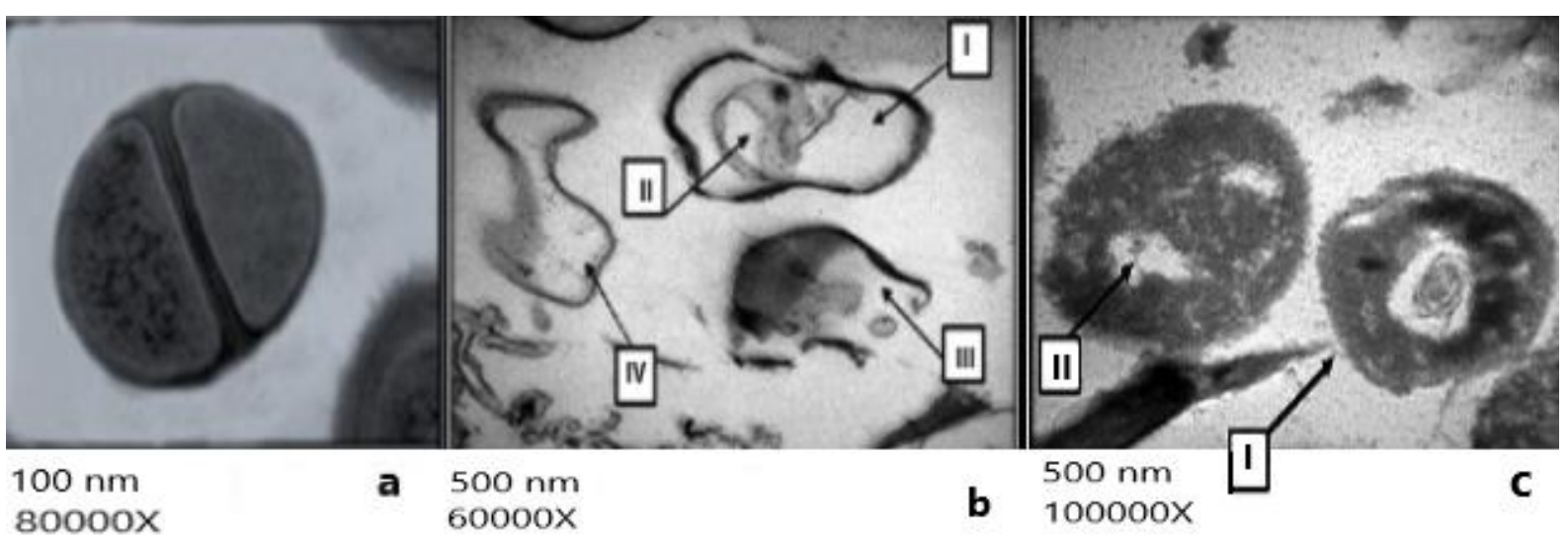

Figures 1: Transmission electron micrograph of methicillin-resistant Staphylococcus aureus (MRSA): (a) untreated, (b) treated with Vespa orientalis venom (minimum inhibitory concentrations: $2.0 \times 10^{-8} \mathrm{mg} / \mathrm{mL}$ ), I and II: loss of cytoplasmic electron density, III: cell rupture and loss of its contents, IV: contraction of cytoplasmic contents, and (c) treated with tetracycline antibiotic (minimum inhibitory concentrations: $2.0 \times 10^{-3} \mathrm{mg} / \mathrm{mL}$ ) normal cell division, I: membrane blebbing, II: cytoplasm lost its electron density properties.

Treatment of Bacillus subtilis with the V. orientalis venom (MIC: $2.0 \times 10^{-7} \mathrm{mg} / \mathrm{mL}$ ) showed detachment of membrane layers (Figure 2b). Tetracycline (MIC: $2.0 \times 10^{-5}$ $\mathrm{mg} / \mathrm{mL}$ ) also induced membrane detachment in Bacillus subtilis (Figure 2c).

The ultrastructure of untreated Escherichia coli showed a distinct membrane with clear normal cilia for movement (Figure 3a). Treatment of Escherichia coli with the $V$. orientalis venom (MIC: $2.0 \times 10^{-4} \mathrm{mg} / \mathrm{mL}$ ) showed membrane blebbing, detachment, and folding (Figure 3b). Tetracycline (MIC: $2.0 \times 10^{-3}$ ) induced shrinkage of cytoplasmic material (Figure 3c). 


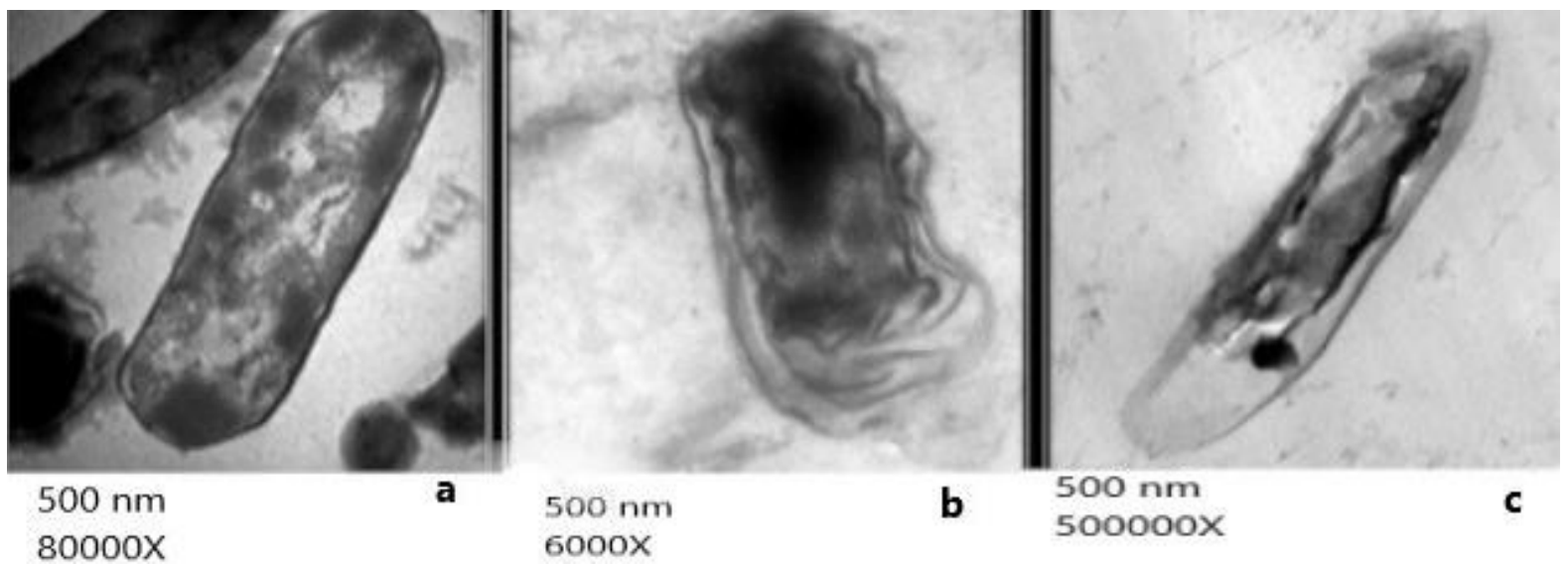

Figure 2: Transmission electron micrograph of Bacillus subtilis: (a) untreated, (b and c) treated with Vespa orientalis venom (minimum inhibitory concentrations: $2.0 \times 10^{-7} \mathrm{mg} / \mathrm{mL}$ ) and tetracycline (minimum inhibitory concentrations: $2.0 \times 10^{-3} \mathrm{mg} / \mathrm{mL}$ ), respectively, showed membrane detachment.

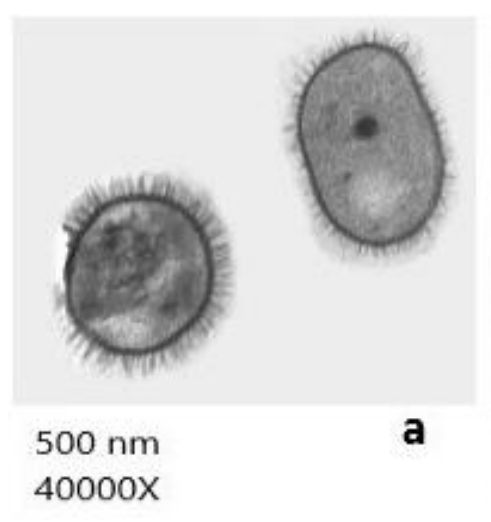

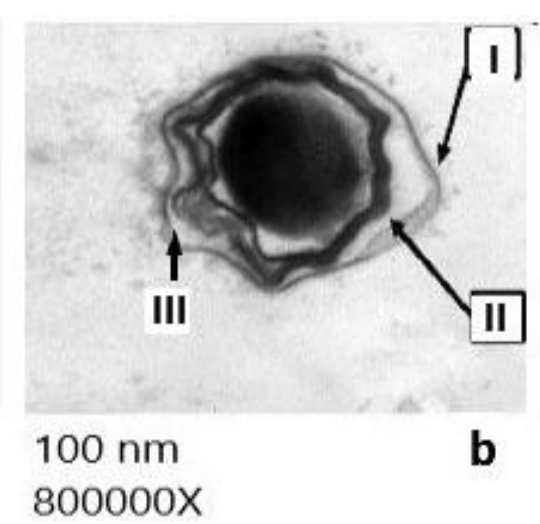

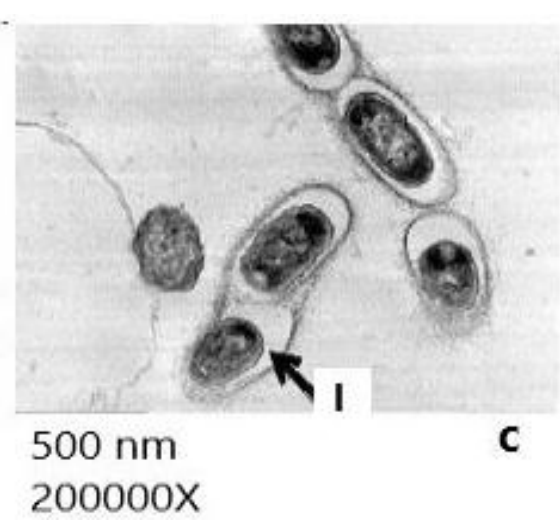

Figure 3: Transmission electron micrograph of Escherichia coli: (a) untreated, (b) treated with Vespa orientalis venom (minimum inhibitory concentrations: $2.0 \times 10^{-4} \mathrm{mg} / \mathrm{mL}$ ), I: membrane blebbing, II: membrane detachment, and III: membrane folding (c) treated with tetracycline (minimum inhibitory concentrations: $2.0 \times 10^{-3} \mathrm{mg} / \mathrm{mL}$ ). I: shrinkage of cytoplasmic material.

\section{DISCUSSION}

Bacterial diseases are considered major global health problems, with emerging of antimicrobial resistance. Commonly, simple infections may become life-threating after increasing resistance to traditional antibiotics $^{[13]}$. The lack of effective treatments against resistant bacteria created a global health problem ${ }^{[14]}$. Most of antimicrobial agents are effective against either Grampositive or Gram-negative bacteria lacking broad-spectrum activity ${ }^{[15,16]}$. Gram-negative bacteria are characterized by the presence of a double membrane making difficulty to treat these bacteria due to many antibiotics cannot penetrate the double membrane or are degraded/modified in the periplasmic space $^{[17]}$. The most predominant Gramnegative pathogens are Escherichia coli, Klebsiella pneumoniae, Enterobacter sp., Serratia sp., Pseudomonas aeruginosa, and Salmonella typhimurium ${ }^{[18,19]}$, most of them acquired resistance to known antibiotics ${ }^{[20,21]}$.

To address the rapid emergence of resistance to the classical antibiotics, naturally occurring antibacterial agents are promising candidates in the search for novel therapeutic agents ${ }^{[22,23]}$. Antibacterial 
property has been reported for the venoms of a wide variety of animals including venoms of snakes, scorpions, spiders, and wasps; all of which are predatory or parasitic animals ${ }^{[24]}$. However, the actual function of AMPs in these venoms is not clear yet. The $V$. orientalis venom proved its antibacterial activity against Gram-positive and Gramnegative bacteria. In Table "1", MIC of $V$. orientalis venom against Escherichia coli, Klebsiella pneumonia, Bacillus subtilis, and MRSA was 10-1000 folds active than tetracycline. The antimicrobial property of $V$. orientalis venoms is mostly due to their peptides. Many authors detected the antimicrobial properties of different wasp venoms $^{[22,25]}$. Isolated AMPs from the $V$. orientalis venom affected the tested bacterial ultrastructure (Figures 1-3). It may also alter cell permeability leading to efflux of essential ions and nutrients, as well as causing the formation of pores and bacterial death ${ }^{[26-30]}$. AMPs can selectively target bacterial membranes due to the presence of lipopolysaccharide and absence of negatively charged lipids on the surface of eukaryotic cells ${ }^{[31,32]}$. The broad-spectra of antibacterial activity of AMPs suggested them as excellent candidates for the development of bacterial antibiotics. Few AMPs were tested in clinical study for prevention of diabetic foot ulcers and being effective against antimicrobialresistant bacteria ${ }^{[33,34]}$.

The detected ultrastructural changes of venom-treated cells proved that interaction with the cell membrane is one of the proposed mechanisms explaining the potency of $V$. orientalis venom. As proteins, peptides comprise the main components of wasp venoms such as phospholipases, hyaluronidase, serotonin, histamine, dopamine, and adrenaline ${ }^{[35-37]}$. Phospholipases hydrolyze the ester bonds and destroy the phospholipid layers in the bacterial cell wall, while hyaluronidase enzyme split polymers and destroy the cellular matrix of the bacterial cells ${ }^{[35]}$. Our proteomic approach revealed several peptides of the $V$. orientalis venom, most of them are previously isolated and identified. Upon separation of the $V$. orientalis venom proteins by SDS-PAGE, seven peptides of low- and high-molecular weights ranging from 60.9 to $310.0 \mathrm{kDa}$ had been observed. Our result was consistent with previously report of Vincent et $a l .{ }^{[37]}$, who analyzed venom proteins of Chelonus inanitus and detected peptide bands with molecular weights ranged from 300 to $60 \mathrm{KDa}$. Although high molecular weight peptides are rarely obtained from the $V$. orientalis venoms, our isolated fraction similar to that separated by Pessoa et al. $^{[38]}$ after using SDS-PAGE analysis of Neoponera villosa venom. Venomous proteins of high molecular weights are responsible for the paralytic activity of solitary spider wasp "Anoplius samariensis" that used spider as a food source for its larvae ${ }^{[39]}$. The $V$. orientalis peptide bands of $227.89 \mathrm{kDa}$ and $186.84 \mathrm{kDa}$ were previously identified by Bruschini et $a .^{[40]}$ as undecenyl propanoate and 2- nonanyl acetate in the venom of Polistes gallicus. They stated that these volatile compounds may be as an alarm pheromone, which trigger defensive responses from nearby insects ${ }^{[40]}$. The peptide band of molecular weight $68.94 \mathrm{kDa}$ isolated from $V$. orientalis venom was detected before by Abt and Rivers ${ }^{[41]}$ from crude venom of the ectoparasitic wasp "Nasonia vitripennis" and characterized as phenoloxidase enzyme, which appears to play an important role in cell death. The peptide band of $V$. orientalis venom with $60 \mathrm{kDa}$ is similar to that detected by Moreno and Giralt ${ }^{[35]}$. This peptide was identified before as phosphatase enzyme, which is not related to venom toxicity, and was also detected in ant venom of Paraponera cribrinodis and Pogonomyrmex badius $^{[42]}$, as well as honey bee venom ${ }^{[43]}$.

The current study suggested that the $V$. orientalis venom and its active AMPs are biologically active peptides and can help in breaking antibiotic resistance between bacterial pathogens, which may encourage the practical application of $V$. orientalis venom in clinical studies. 


\section{ACKNOWLEDGMENTS}

This research received no specific grant from any funding agency in the public, commercial or non-profit sectors.

\section{CONFLICT OF INTEREST}

The authors declare no conflict of interest.

\section{AUTHORS' CONTRIBUTIONS}

MHR, DMM, and AKA planned the study. MHR and DMM designed all experiments. AEA and EEE carried out the experiments. AEA and DMM performed venom protein analysis and analyzed TEM results. MHR, DMM, and AEA summarized, discussed, and interpreted the results. MHR, DMM, and EEE drafted the manuscript.

\section{REFERENCES}

[1] Rady, M. H.; Essa, E. E.; Ma'moun, S. A. M. et al. (2018). Characterization and solubilization of chitosan from the oriental hornet (Vespa orientalis). J Egypt Soc Parasitol, 48(3): 669-676.

[2] Essa, E. E.; Mo'men, S. A. A.; Rady, M. H. et al. (2019). Eucalyptus oil nano-emulsion encapsulated in chitosan beads as a new approach in control of Culex pipiens larvae. Int $\mathrm{J}$ Mosq Res, 6(5): 63-69.

[3] Dongol, Y.; Dhananjaya, B. L.; Shrestha, R. K. et al. (2014). Pharmacological and immunological properties of wasp venom (Chapter 3 , DOI: 10.5772/57227). In: Pharmacology and Therapeutics (Gowder, S. J. T., ed). IntechOpen, London, UK.

[4] Moreau, S. J. M. (2013). "It stings a bit but it cleans well": venoms of Hymenoptera and their antimicrobial potential. J Insect Physiol, 59(2): 1862044.

[5] León-Buitimea, A.; Garza-Cárdenas, C. R.; Garza-Cervantes, J. A. et al. (2020). The demand for new antibiotics: antimicrobial peptides, nanoparticles, and combinatorial therapies as future strategies in antibacterial agent design. Front Microbiol, 11: 1669 (DOI: 10.3389/fmicb.2020.01669).

[6] Antimicrobial Resistance (2020). World Health Organization (https://www.who.int/news-room/factsheets/detail/antimicrobial-resistance).

[7] Sanad, R. E., and Mohanny, K. M. (2013). The efficacy of a new modified apparatus for collecting bee venom in relation to some biological aspects of honeybee colonies. J Am Sci, 9: 177-182.

[8] Collee, J. G.; Fraser, A. G.; Marmion, B. P. et al. (1996). Mackie \& McCartney Practical Medical Microbiology. Churchill Livingstone, London, UK.

[9] Jalaei, J.; Fazeli, M.; Rajaian, H. et al. (2014). In vitro antibacterial effect of wasp (Vespa orientalis) venom. J Venom Anim Toxins Incl Trop Dis, 20: 22 (DOI: 10.1186/16789199-20-22).

[10] Holder, I. A. and Boyce, S. T. (1994). Agar well diffusion assay testing of bacterial susceptibility to various antimicrobials in concentrations non-toxic for human cells in culture. Burns, 20(5): 426-429.

[11] Fultz, B. and Howe, J. M. (2013). Transmission Electron Microscopy and Diffractometry of Materials. Springer-Verlag, Heidelberg, Germany.

[12] Gallagher, S. R. and Smith, J. A. (1987). Denaturing (SDS) discontinuous gel electrophoresis: Laemmli gel method. In: Current Protocols in Molecular Biology, basic protocol, unit 10.2.4-10.2.6 (Ausubel, F. M.; Brent, R.; Kingston, R. E. et al., eds). Wiley and Sons Inc., New York, NY, USA.

[13] González-Bello, C. (2017). Antibiotic adjuvants - a strategy to unlock bacterial resistance to antibiotics. Bioorg Med Chem Lett, 27(18): 42214228.

[14] Giamarellou, H. (2010). Multidrugresistant Gram-negative bacteria: how 
to treat and for how long. Int $\mathrm{J}$ Antimicrob Agents, 36: S50-S54.

[15] Talbot, G. H.; Bradley, J.; Edwards, J. E. et al. (2006). Bed bugs need drugs: an update on the development pipeline from the antimicrobial availability task force of the infectious diseases society of America. Clin Infect Dis, 42(5): 657-668.

[16] Nicasio, A. M.; Kuti, J. L. and Nicolau, D. P. (2008). The current state of multidrug-resistant Gramnegative bacilli in America, insights from the society of infectious diseases pharmacists. Pharmacotherapy, 28(2): 235-249.

[17] Beveridge, T. J. (1999). Structures of Gram-negative cell walls and their derived membrane vesicles. J Bacteriol, 181(16): 4725-4733.

[18] Weinstein, R. A.; Gaynes, R.; Edwards, J. R. et al. (2005). Overview of nosocomial infections caused by gram-negative bacilli. Clin Infect Dis, 41(6): 848-854.

[19] Chopra, I.; Schofield, C.; Everett, M. et al. (2008). Treatment of healthcare-associated infections caused by Gram-negative bacteria: a consensus statement. Lancet Infect Dis, 8(2): 133-139

[20] Smolinski, M. S.; Hamburg, M. A. and Lederberg, J. (2003). Microbial Threats to Health: Emergence, Detection, and Response. National Academies Press, Washington, DC, USA.

[21] Diekema, D.; BootsMiller, B.; Vaughn, T. et al. (2004). Antimicrobial resistance trends and outbreak frequency in United States hospitals. Clin Infect Dis, 38(1): 7885.

[22] Zasloff, M. (2002). Antimicrobial peptides of multicellular organisms. Nature, 415(6870): 389-395.

[23] Giuliani, A.; Pirri, G. and Nicoletto, S. F. (2007). Antimicrobial peptides: an overview of a promising class of therapeutics. Cent Eur J Biol, 2: 1-33.
[24] Yacoub, T.; Rima, M.; Karam, M. et al. (2020). Antimicrobials from venomous animals: an overview. Molecules, 25(10): 2402 (DOI: 10.3390/molecules25102402).

[25] Dos Santos Cabrera, M. P.; Rangel, M.; Ruggiero Neto, J. et al. (2019). Chemical and biological characteristics of antimicrobial $\alpha$ helical peptides found in solitary wasp venoms and their interactions with model membranes. Toxins (Basel), 11(10): 559 (DOI: 10.3390/ toxins11100559).

[26] Giangaspero, A.; Sandri, L. and Tossi, A. (2001). Amphipathic $\alpha$ helical antimicrobial peptides: a systematic study of the effects of structural and physical properties on biological activity. Eur J Biochem, 268(21): 5589-5600.

[27] Peters, B. M.; Shirtliff, M. E. and Jabra-Rizk, M. A. (2010). Antimicrobial peptides: primeval molecules or future drugs? PLoS Pathog, 6(10): e1001067 (DOI: 10.1371/journal.ppat.1001067).

[28] Yeung, A. T. Y.; Gellatly, S. L. and Hancock, R. E. W. (2011). Multifunctional cationic host defense peptides and their clinical applications. Cell Mol Life Sci, 68(13): 2161-2176.

[29] Chan, D. I.; Prenner, E. J. and Vogel, H. J. (2006). Tryptophan- and arginine-rich antimicrobial peptides: structures and mechanisms of action. Biochim Biophys Acta, 1758(9): 11841202.

[30] Dawson, R. M. and Liu, C.-Q. (2008). Properties and applications of antimicrobial peptides in biodefense against biological warfare threat agents. Crit Rev Microbiol, 34(2): 89-107.

[31] Patrzykat, A.; Friedrich, C. L.; Zhang, L. et al. (2002). Sublethal concentrations of pleurocidin-derived antimicrobial peptides inhibit macromolecular synthesis in Escherichia 
coli. Antimicrob Agents Chemother, 46(3): 605-614.

[32] Harris, M.; Mora-Montes, H. M.; Gow. N. A. R. et al. (2009). Loss of mannosylphosphate from Candida albicans cell wall proteins results in enhanced resistance to the inhibitory effect of a cationic antimicrobial peptide via reduced peptide binding to the cell surface. Microbiology, 155: 1058-1070.

[33] Hancock, R. E. W. and Sahl, H.-G. (2006). Antimicrobial and hostdefense peptides as new anti-infective therapeutic strategies. Nat Biotechnol, 24(12): 1551-1557.

[34] Park, S.-C.; Park, Y. and Hahm, K.-S. (2011). The role of antimicrobial peptides in preventing multidrugresistant bacterial infections and biofilm formation. Int J Mol Sci, 12(9): 5971-5992.

[35] Moreno, M. and Giralt, E. (2015). Three valuable peptides from bee and wasp venoms for therapeutic and biotechnological use: melittin, apamin and mastoparan. Toxins (Basel), 7(4): 1126-1150.

[36] Coudron, T. A.; Knop Wright, M. M.; Puttler, B. et al. (2000). Effect of the ectoparasite Necremnus breviramulus (Hymenoptera: Eulophidae) and its venom on natural and factitious hosts. Ann Entomol Soc Am, 93(4): 890-897.

[37] Vincent, B.; Kaeslin, M.; Roth, T. et al. (2010). The venom composition of the parasitic wasp Chelonus inanitus resolved by combined expressed sequence tags analysis and proteomic approach. BMC genomics, 11: 693 (DOI: 10.1186/1471-2164-11-693).

[38] Pessoa, W. F. B.; Silva, L. C. C.; de Oliveira Dias, L. et al. (2016). Analysis of protein composition and bioactivity of Neoponera villosa venom (Hymenoptera: Formicidae). Int J Mol Sci, 17(4): 513 (DOI: 10.3390/ijms17040513).

[39] Hisada, M.; Satake, H.; Masuda, K. et al. (2005). Molecular components and toxicity of the venom of the solitary wasp, Anoplius samariensis. Biochem Biophys Res Commun, 330(4): 1048-1054.

[40] Bruschini, C.; Cervo, R. and Turillazzi, S. (2006). Evidence of alarm pheromones in the venom of Polistes dominulus workers (Hymenoptera: Vespidae). Physiol Entomol, 31(3): 286-293.

[41] Abt, M. and Rivers, D. B. (2007). Characterization of phenoloxidase activity in venom from the ectoparasitoid Nasonia vitripennis (Walker) (Hymenoptera:Pteromalidae). J Invertebr Pathol, 94(2): 108-118.

[42] Touchard, A.; Labrière, N.; Roux, O. et al. (2014). Venom toxicity and composition in three Pseudomyrmex ant species having different nesting modes. Toxicon, 88: 67-76.

[43] Grunwald, T.; Bockisch, B.; Spillner, E. et al. (2006). Molecular cloning and expression in insect cells of honeybee venom allergen acid phosphatase (Api m 3). J Allergy Clin Immunol, 117(4): 848-854.

\section{How to cite this article:}

Amer, A. E.; Essa, E. E.; Rady, M. H.; Al-Sayed, A. K. and Mahmoud, D. M. (2021). Antibacterial activity and mechanism of action of the WASP Vespa orientalis venom peptides. Egyptian Journal of Zoology, 75: 60-69 (DOI: 10.12816/ejz.2021.50281.1045). 


\section{"VESPA ORIENTALIS" النشاط المضاد للبكتيريا وآلية عمل ببتيدات سُم الدبور}

\section{أسماء ابراهيم عامر، إيمان عيسي فهمي، ماجده حسن راضي، عادل كمال السيد، داليا محمد محمود}

قسم علم الحشر ات، كلية العلوم، جامعة عين شمس، القاهرة، جمهورية مصر العربية

تم تحديد العديد من الحشرات مؤخرًا على أنها ناقلات محتملة للبييتيدات المضاده للميكروبات، و التي لها نشاط

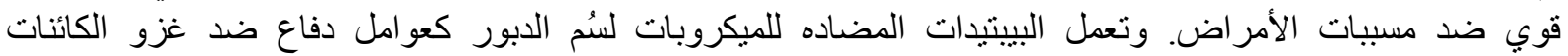

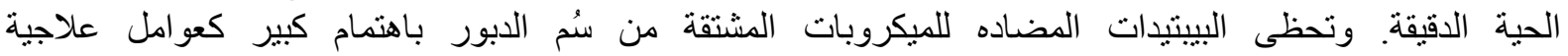

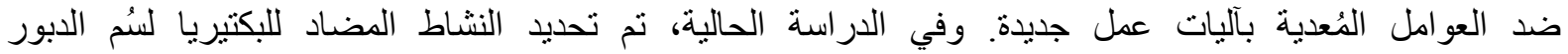
(Hymenoptera: Vespidae) Vespa orientalis L."

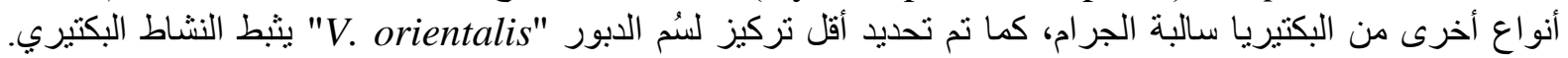

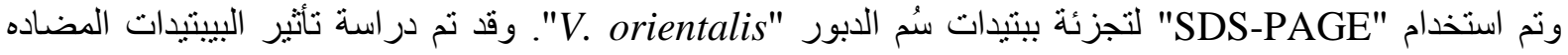

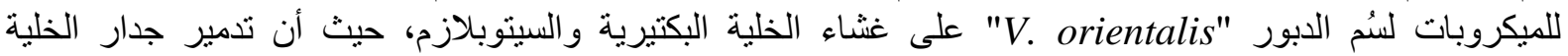

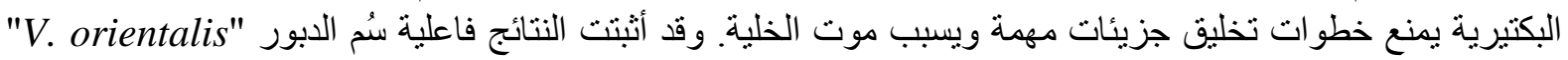

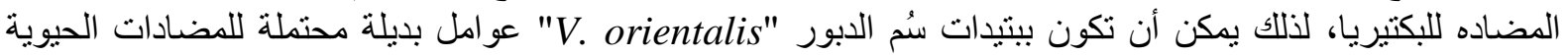

